Article

\title{
Synthesis of Ni-Co Hydroxide Nanosheets Constructed Hollow Cubes for Electrochemical Glucose Determination
}

\author{
Fengchao Sun ${ }^{1,2}$, Shutao Wang ${ }^{3}$, Yuqi Wang ${ }^{3}$, Jingtong Zhang ${ }^{2}$, Xinping Yu ${ }^{2}$, Yan Zhou ${ }^{1,2,3, *}$ \\ and Jun Zhang ${ }^{1,2}$ \\ 1 School of Materials Science and Engineering, China University of Petroleum (East China), \\ Qingdao 266580, China \\ 2 School of Chemical Engineering, China University of Petroleum (East China), Qingdao 266580, China \\ 3 College of Science, China University of Petroleum (East China), Qingdao 266580, China \\ * Correspondence: yanzhou@upc.edu.cn
}

Received: 30 May 2019; Accepted: 1 July 2019; Published: 3 July 2019

\begin{abstract}
Hierarchical Ni-Co double transition metal hydroxide nanosheets have been explored as an effective strategy for the design of nonenzymatic glucose sensors. Ni-Co hydroxide nanosheets constructed hollow cubes were successfully synthesized by using $\mathrm{Cu}_{2} \mathrm{O}$ cubes as templates and subsequently etched by $\mathrm{Na}_{2} \mathrm{~S}_{2} \mathrm{O}_{3}$ to achieve a hollow cubic structure. The molar ratio between $\mathrm{Ni}$ and Co was tuned by varying the precursor ratio of $\mathrm{NiCl}_{2}$ and $\mathrm{CoCl}_{2}$. It was observed by transmission electron microscopy (TEM) that the increasing Ni precursor resulted in particle morphology, and the increasing ratio of the Co precursor resulted in more lamellar morphology. The sample with the composition of $\mathrm{Ni}_{0.7} \mathrm{Co}_{0.3}(\mathrm{OH})_{2}$ displayed the best performance for glucose sensing with high selectivity (1541 $\left.\mu \mathrm{A} \mathrm{mM}^{-1} \mathrm{~cm}^{-2}\right)$, low detection limit (3.42 $\mu \mathrm{M}$ with $\left.\mathrm{S} / \mathrm{N}=3\right)$, and reasonable selectivity. Similar strategies could be applied for the design of other electrode materials with high efficiency for nonenzymatic glucose determination.
\end{abstract}

Keywords: Nonenzymatic; glucose sensor; electrochemical sensor; double hydroxides

\section{Introduction}

Determination of glucose is of rising significance to the public because of its crucial function in human life activities [1-3]. Abnormal blood levels of glucose can cause serious health issues, including diabetes mellitus $[4,5]$. Therefore, fast and accurate determination of glucose is urgently demanded. The electroanalytical method has been proven to be one of the most promising ways for measuring the glucose concentration, with high sensitivity and relatively low cost, since Clark et al. introduced the concept of an enzymatic electrochemical glucose sensor more than 50 years ago [6]. Although three generations of enzymatic glucose sensors have been developed, the enzyme-based electrochemical sensor still suffers from low thermal stability, low chemical stability, high costs, and restricted working conditions (e.g., temperature and $\mathrm{pH}$ ) due to the nature of the enzyme $[7,8]$.

Therefore, enzyme-free electrochemical sensors have been developed and have demonstrated excellent sensory performances thanks to their thermal and chemical stability [9-16]. The mechanism of the nonenzymatic glucose sensor is similar to that of the enzymatic catalytic process, which oxidizes glucose to gluconolactone $[17,18]$. Therefore, multi-valence transition metal based electrocatalysts can be ideal for the electrochemical catalytic oxidation of glucose. Electrochemical oxidation of transition-metal-based compounds in the aqueous condition usually causes the formation of metal oxides or hydroxides on the surface of catalysts; therefore, the electrochemical catalytic oxidation of glucose on transition-metal-based compounds are usually achieved by the oxidation of surface 
hydroxides to oxyhydroxides [17]. More recently, double-metal hydroxides (DMHs) haven been intensively investigated for electrocatalytic purposes [19-27]. It was found that the introduction of the second metal ion into metal hydroxides can significantly tune the electronic structure, thus leading to faster electron transfer kinetics [28]. DMHs, including Ni/Al [27], NiCo [28], NiFe [29], CoFe [30], etc., have been studied for nonenzymatic glucose sensing. Additionally, the electrocatalytic performances of the electrode materials could also boost through the rational design of the hierarchical structures, owing to the increased active surface area, improved glucose diffusion pathways, and the tuned conductivity. Therefore, hierarchical hollow structures often show excellent glucose detection performances because of their high surface-to-volume ratios and large specific surface areas.

Herein, a hollow hierarchical structure is reported by arraying NiCo hydroxide nanosheets on $\mathrm{Cu}_{2} \mathrm{O}$ cubes followed by chemical etching. It was then used as an electrode material for a nonenzymatic electrochemical glucose sensor. Furthermore, the $\mathrm{Ni}$ and $\mathrm{Co}$ ratio was tuned by changing precursor ratios, and the composition of $\mathrm{Ni}_{0.7} \mathrm{Co}_{0.3}(\mathrm{OH})_{2}$ displayed the best performance among other ratios towards electrochemical glucose oxidation.

\section{Materials and Methods}

\subsection{Materials}

In the experiment, all reagents were analytically pure and used directly. Cupric (II) chloride $\left(\mathrm{CuCl}_{2} \bullet 2 \mathrm{H}_{2} \mathrm{O}\right)$, nickel (II) chloride $\left(\mathrm{NiCl}_{2} \bullet 6 \mathrm{H}_{2} \mathrm{O}\right)$, cobaltous (II) chloride $\left(\mathrm{CoCl}_{2} \bullet 6 \mathrm{H}_{2} \mathrm{O}\right)$, and sodium hydroxide $(\mathrm{NaOH})$ were bought from Xilong Chemical Co., Ltd. (Guangdong, China). D-(+)-glucose $\left(\mathrm{C}_{6} \mathrm{H}_{12} \mathrm{O}_{6} \bullet 4 \mathrm{H}_{2} \mathrm{O}\right)$, D-(+)-galactose $\left(\mathrm{C}_{6} \mathrm{H}_{12} \mathrm{O}_{6}\right)$, L-ascorbic acid $\left(\mathrm{C}_{6} \mathrm{H}_{8} \mathrm{O}_{6}\right)$, Polyvinylpyrrolidone $\mathrm{K} 30$ (PVP-K30), fructose, and ethanol absolute $\left(\mathrm{C}_{2} \mathrm{H}_{6} \mathrm{O}\right)$ were purchased from Sinopharm Chemical Reagent Co., Ltd. (Shanghai, China). Uric acid $\left(\mathrm{C}_{5} \mathrm{H}_{4} \mathrm{~N}_{4} \mathrm{O}_{3}\right)$ was bought from TCI (Shanghai, China). Acetaminophen was purchased from Shanghai Civi Chemical Technology Co., Ltd., and 5\% Nafion solution was from Alfa Aesar (Shanghai, China).

\subsection{Synthesis of $\mathrm{Cu}_{2} \mathrm{O}$ Cubes}

The template of $\mathrm{Cu}_{2} \mathrm{O}$ cubes was synthesized as reported in a previous reference [31]. A total of $0.17 \mathrm{~g} \mathrm{CuCl}_{2} \bullet 2 \mathrm{H}_{2} \mathrm{O}$ was dissolved in $100 \mathrm{~mL}$ deionized water, then the solution was heated to $55^{\circ} \mathrm{C}$ and stirred for $30 \mathrm{~min}$. Afterward, $10 \mathrm{~mL} 2 \mathrm{M} \mathrm{NaOH}$ was added dropwise into the above solution to form a brown suspension. After stirring at $55^{\circ} \mathrm{C}$ for $30 \mathrm{~min}, 10 \mathrm{~mL} 0.6 \mathrm{M}$ ascorbic acid solution was added dropwise into the system and was continuously stirred at $55^{\circ} \mathrm{C}$ for $3 \mathrm{~h}$. The color of the suspension changed to brick red. The resulting precipitate was then collected by filtration, followed by washing with deionized water three times and ethanol once, and finally dried in a vacuum at $60^{\circ} \mathrm{C}$ for $12 \mathrm{~h}$.

\subsection{Synthesis of Ni-Co Hydroxide Nanosheets}

The hollow cubic $\mathrm{Ni}_{\mathrm{x}} \mathrm{Co}_{1-\mathrm{x}}(\mathrm{OH})_{2}$ nanosheets were synthesized using a method reported

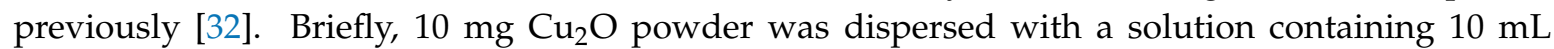
ethanol and $10 \mathrm{~mL}$ deionized water. After $30 \mathrm{~min}$ of ultrasonic treatment, $0.33 \mathrm{~g}$ PVP-K30 was added into the system. After another 30 min of ultrasonic treatment, $3.4 \mathrm{mg}$ of $\mathrm{CoCl}_{2} \bullet 6 \mathrm{H}_{2} \mathrm{O}$ and $\mathrm{NiCl}_{2} \bullet 6 \mathrm{H}_{2} \mathrm{O}$ each was added into the suspension and stirred for $30 \mathrm{~min}$. Then, $20 \mathrm{~mL} \mathrm{Na} \mathrm{S}_{2} \mathrm{O}_{3}$ solution was dropped slowly into the system under stirring for $30 \mathrm{~min}$. When the addition finished, the solution was stirred for $40 \mathrm{~min}$ and the color of the system changed from brick red to transparent green, proving the production of $\mathrm{Ni}_{\mathrm{x}} \mathrm{Co}_{1-\mathrm{x}}(\mathrm{OH})_{2}$. The product was gathered by filtration. Afterward, it was washed with deionized water three times and ethanol once, and it was finally dried in a vacuum at $60{ }^{\circ} \mathrm{C}$ for $12 \mathrm{~h}$. By changing the mass ratio of $\mathrm{CoCl}_{2} \bullet 6 \mathrm{H}_{2} \mathrm{O}$ and $\mathrm{NiCl}_{2} \bullet 6 \mathrm{H}_{2} \mathrm{O}, \mathrm{Ni}_{\mathrm{x}} \mathrm{Co}_{1-\mathrm{x}}(\mathrm{OH})_{2}$ could be produced with various designed compositions, such as $\mathrm{Co}(\mathrm{OH})_{2}, \mathrm{Ni}_{0.3} \mathrm{Co}_{0.7}(\mathrm{OH})_{2}, \mathrm{Ni}_{0.5} \mathrm{Co}_{0.5}(\mathrm{OH})_{2}, \mathrm{Ni}_{0.7} \mathrm{Co}_{0.3}(\mathrm{OH})_{2}$, and $\mathrm{Ni}(\mathrm{OH})_{2}$. 


\subsection{Instruments}

X-ray diffraction (XRD) was carried out with a Philips X'Pert diffractometer (PANalytical B.V., Almelo, Holland) under the conditions of $\mathrm{Cu} \mathrm{K} \alpha$ radiation $(\lambda=0.15418 \mathrm{~nm}), 40 \mathrm{kV}$ voltage, and $40 \mathrm{~mA}$ current. Transmission electron microscope (TEM) and high-resolution transmission electron microscope (HRTEM) analyses were tested on a JEM-2100UHR transmission microscope (JEOL, Tokyo, Japan) under a $200 \mathrm{kV}$ testing voltage. X-ray photoelectron spectroscopy (XPS) was carried out using a VGESCALABMK II spectrometer (VG instruments, Suffolk, UK) with an Al K $\alpha(1486.6 \mathrm{eV})$ photon source. Elemental mapping images were tested on an X-Max detector (Oxford instruments, Oxford, UK).

\subsection{Electrochemical Tests}

$4 \mathrm{mg}$ of $\mathrm{Ni}_{\mathrm{x}} \mathrm{Co}_{1-\mathrm{x}}(\mathrm{OH})_{2}$ was dispersed in $900 \mathrm{~mL}$ of ethanol and $100 \mathrm{~mL}$ of Nafion. The suspension was sonicated for $10 \mathrm{~min}$ to gain a homogeneous ink. Carbon paper (CP) was produced with $6 \mathrm{M} \mathrm{HCl}$ solution, acetone, deionized water, and ethanol successively for 30 min under ultrasonic treatment. Then, $10 \mu \mathrm{L}$ of the homogeneous ink was daubed on CP uniformly. After drying in air, the modified electrode was ready for electrochemical measurements.

Electrochemical testing was carried out on a CHI 660E Electrochemical workstation (CH Instruments, Shanghai, China) with the standard three electrodes. A Pt electrode clip with $\mathrm{Ni}_{\mathrm{x}} \mathrm{Co}_{1-\mathrm{x}}(\mathrm{OH})_{2} / \mathrm{CP}$ served as the working electrode. A mercury-mercuric oxide electrode acted as the reference electrode, and a Pt plate acted as the counter electrode. All electrochemical measurements were carried out in a $0.1 \mathrm{M} \mathrm{NaOH}$ electrolyte solution.

\section{Results and Discussion}

\subsection{Structural Characterization of Hierarchical Ni-Co Hydroxide Nanosheets}

The Co-Ni double-metal hydroxides nanosheets assembled hollow cube was synthesized by in situ growth of $\mathrm{Co}-\mathrm{Ni}$ hydroxides on a $\mathrm{Cu}_{2} \mathrm{O}$ cube though a hydrothermal reaction, followed by $\mathrm{Na}_{2} \mathrm{~S}_{2} \mathrm{O}_{3}$ etching to remove $\mathrm{Cu}_{2} \mathrm{O}$ (Figure 1). The ratios of $\mathrm{Ni}$ and $\mathrm{Co}$ were controlled by tuning the reactant ratio of $\mathrm{NiCl}_{2}$ and $\mathrm{CoCl}_{2}$. Figure 2a shows the typical TEM image of the cubic structure of $\mathrm{Cu}_{2} \mathrm{O}$. The double-metal hydroxide of $\mathrm{Ni}_{x} \mathrm{Co}_{1-x}(\mathrm{OH})_{2}$ was then directly grown on a $\mathrm{Cu}_{2} \mathrm{O}$ template with the removal of $\mathrm{Cu}_{2} \mathrm{O}$ to achieve a hollow cubic $\mathrm{Ni}_{\mathrm{x}} \mathrm{Co}_{1-\mathrm{x}}(\mathrm{OH})_{2}$. The ratio between $\mathrm{Ni}$ and Co was controlled by the precursor ratio between $\mathrm{Ni}$ and $\mathrm{Co}$. Figure $2 \mathrm{~b}$ shows the hollow cubic $\mathrm{Ni}_{0.7} \mathrm{Co}_{0.3}(\mathrm{OH})_{2}$. An increasing content of Co resulted in more distinct nanosheet morphology of $\mathrm{Ni}_{\mathrm{x}} \mathrm{Co}_{1-\mathrm{x}}(\mathrm{OH})_{2}$ (Figure S1). The HRTEM image (Figure 2c) shows a clear lattice fringe with $0.261 \mathrm{~nm}$ d-spacing, which consisted of the (101) crystal plane of $\mathrm{Ni}(\mathrm{OH})_{2}$. Energy dispersive spectrometer (EDS) based elemental mapping (Figure $2 \mathrm{~d}-\mathrm{g}$ ) showed evenly distributed $\mathrm{Ni}, \mathrm{Co}$, and $\mathrm{O}$, indicating that the Ni-Co hydroxide was successfully synthesized. Figure $2 \mathrm{~h}$ shows the XRD patterns of $\mathrm{Cu}_{2} \mathrm{O}$ cubic templates, which consisted of the reference data (PDF No. 05-0667). Figure 1i shows the XRD patterns of Ni-Co hydroxides with different Ni-Co ratios. The peaks of (101) and (110) crystal planes were clearly observed for $\mathrm{Co}(\mathrm{OH})_{2}, \mathrm{Ni}(\mathrm{OH})_{2}$ and Ni-Co hydroxides, with slight shifts in the diffraction angles, suggesting continuous variations of $\mathrm{Ni}-\mathrm{Co}$ ratios. It is clear that the increasing content of $\mathrm{Co}$ in Ni-Co hydroxide results in the appearance of a peak at $9.5^{\circ}$, suggesting a nanosheet morphology predominates when Co content is high. This agreed well with the TEM findings.

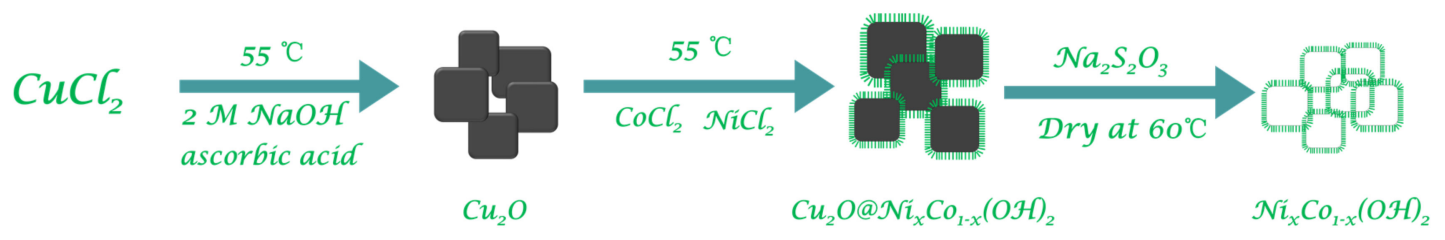

Figure 1. Schematic diagram of the synthetic procedure for the Co-Ni hydroxide nanosheets assembled the hollow cubic structures. 

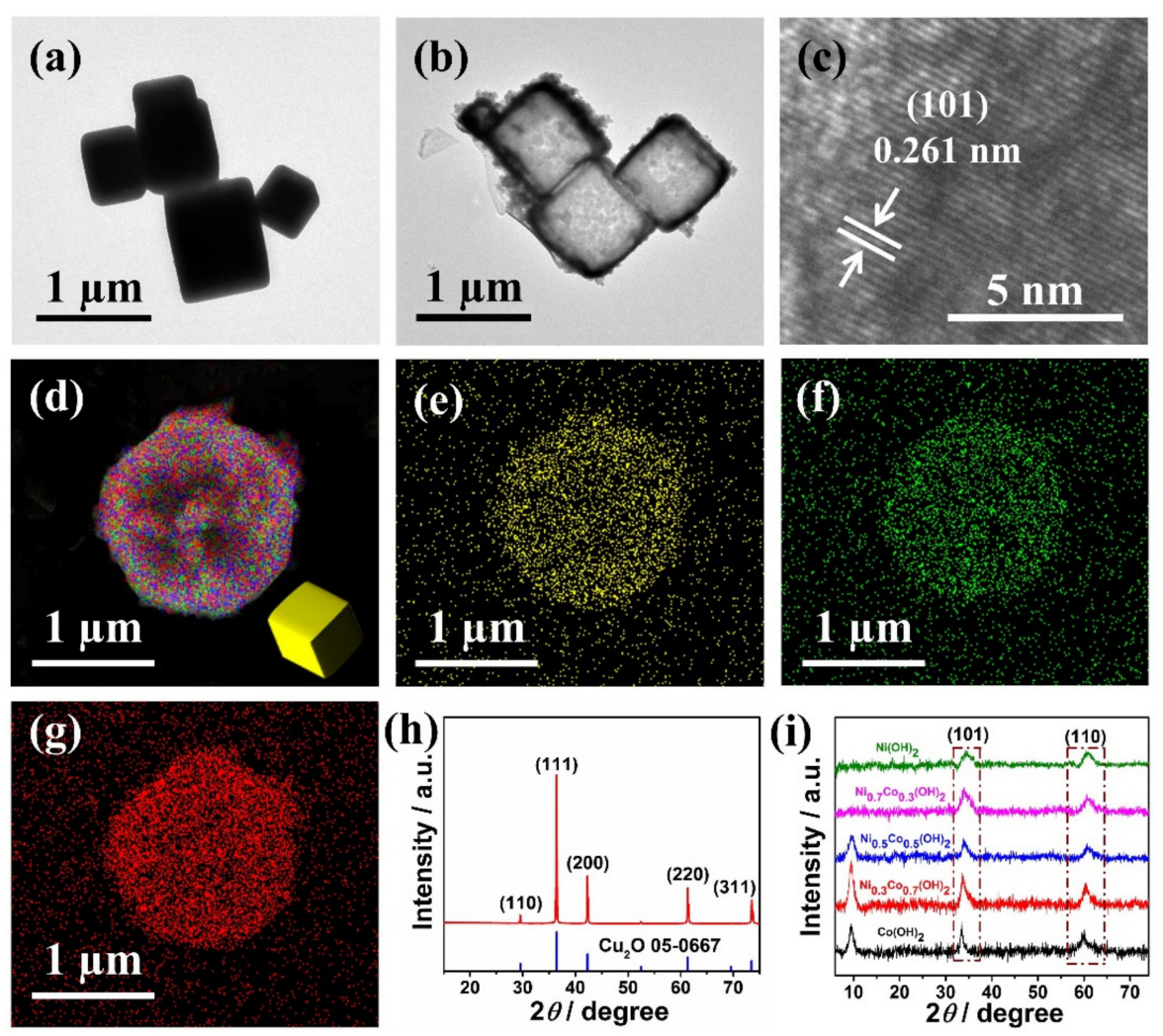

Figure 2. Transmission electron microscopy (TEM) images of (a) $\mathrm{Cu}_{2} \mathrm{O}$ and $(\mathbf{b}) \mathrm{Ni}_{0.7} \mathrm{Co}_{0.3}(\mathrm{OH})_{2}$ hollow cubes. (c) High-resolution transmission electron microscope (HRTEM) image of $\mathrm{Ni}_{0.7} \mathrm{Co}_{0.3}(\mathrm{OH})_{2}$. (d-g) EDS mapping of $\mathrm{Ni}_{0.7} \mathrm{Co}_{0.3}(\mathrm{OH})_{2}$ hollow cubes. The X-ray diffraction (XRD) patterns of $(\mathbf{h}) \mathrm{Cu}_{2} \mathrm{O}$ and (i) $\mathrm{Ni}_{0.7} \mathrm{Co}_{0.3}(\mathrm{OH})_{2}$ hollow cubes with different $\mathrm{Ni}$-Co ratios.

X-ray photoelectron spectroscopy (XPS) analyses were carried out to further verify the surface composition and oxidation states of $\mathrm{Ni}_{0.7} \mathrm{Co}_{0.3}(\mathrm{OH})_{2}$ hollow cubes. Figure 3 a shows the complete XPS spectrum survey of $\mathrm{Ni}_{0.7} \mathrm{Co}_{0.3}(\mathrm{OH})_{2}$, where there are featured peaks of $\mathrm{Ni} 2 \mathrm{p}, \mathrm{Co} 2 \mathrm{p}, \mathrm{O}$ 1s and $\mathrm{C} 1 \mathrm{~s}$. The core-level spectrums for $\mathrm{Ni} 2 \mathrm{p}, \mathrm{Co} 2 \mathrm{p}$, and $\mathrm{O} 1 \mathrm{~s}$ were further analyzed to acquire detailed oxidation states and local electronic environments for $\mathrm{Ni}, \mathrm{Co}$, and $\mathrm{O}$. Figure $3 \mathrm{~b}$ displays the core-level spectrum in the Ni $2 p$ region. Six curves were deconvoluted in order to obtain a reasonable fitting for Ni $2 p$. The peaks at 855.6 and $873.2 \mathrm{eV}$ can be ascribed to the $\mathrm{Ni}^{2+}$ oxidation state, and another two peaks with the binding energies of 856.9 and $874.7 \mathrm{eV}$ can be assigned to the $\mathrm{Ni}^{3+} 2 \mathrm{p}$ spin orbits. The core level XPS spectrum of Co 2p is shown in Figure 3c. Two valence states of $\mathrm{Co}^{3+}$ and $\mathrm{Co}^{2+}$ for cobalt species were found. The peaks at 780.5 and $795.9 \mathrm{eV}$ are ascribed to the $2 \mathrm{p}_{3 / 2}$ and $2 \mathrm{p}_{1 / 2}$ states of $\mathrm{Co}^{3+}$. Similarly, the peaks appearing at 781.9 and $797.2 \mathrm{eV}$ are attributed to the $2 \mathrm{p}_{3 / 2}$ and $2 \mathrm{p}_{1 / 2}$ of $\mathrm{Co}^{2+}$ pieces. These results confirm that both $\mathrm{Co}$ and $\mathrm{Ni}$ elements have mixed oxidation states in $\mathrm{Ni}_{0.7} \mathrm{Co}_{0.3}(\mathrm{OH})_{2}$ samples, which agrees well with previous reports [33]. This composition is similar to that of Ni-Co double-layered hydroxide [28]. Furthermore, the XPS core-level spectrum of O 1s shown in Figure 3d displays three deconvoluted peaks with binding energies of 530.3, 531.4, and $532.8 \mathrm{eV}$, which can be attributed to the metal-bonding oxygen, hydroxyl oxygen, and surface oxygen caused by physical or chemical adsorption, respectively [34]. 
(a)
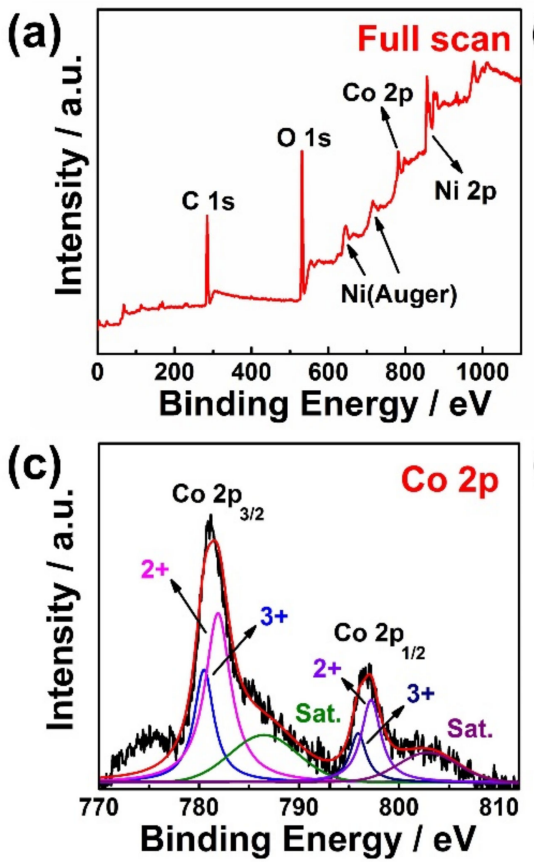
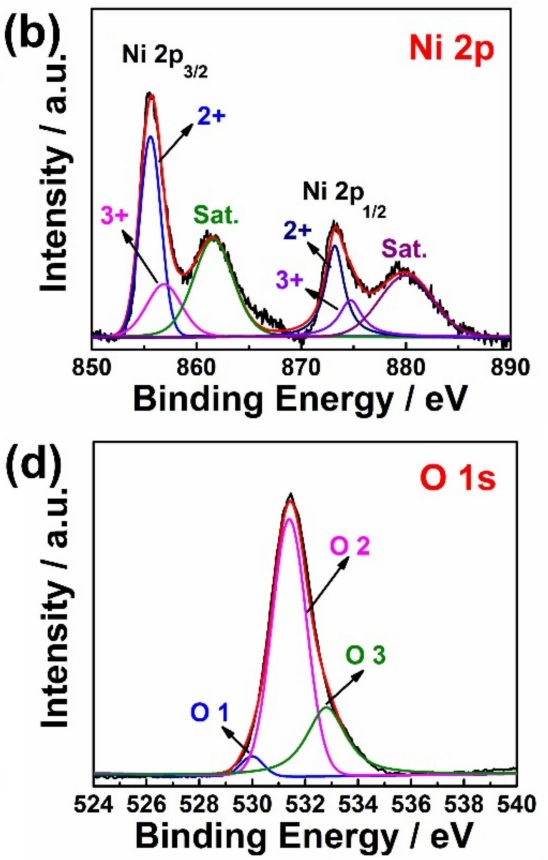

Figure 3. X-ray photoelectron spectroscopy (XPS) spectra of $\mathrm{Ni}_{0.7} \mathrm{Co}_{0.3}(\mathrm{OH})_{2}(\mathbf{a})$ full survey and in the core spectrum region of (b) Ni 2p, (c) Co 2p, and (d) O 1s.

\subsection{Electrochemical Characterization of Hierarchical Ni-Co Hydroxide Nanosheets}

Electrochemical methods were further carried out on the hierarchical Ni-Co hydroxide nanosheets in order to understand their redox behaviors. Figure 3a shows the cyclic voltammograms of the $\mathrm{Ni}_{0.7} \mathrm{Co}_{0.3}(\mathrm{OH})_{2}$ drop-casted carbon paper $\left(\mathrm{Ni}_{0.7} \mathrm{Co}_{0.3}(\mathrm{OH})_{2} / \mathrm{CP}\right)$ electrode scanned from $+0.2 \mathrm{~V}$ to $+0.8 \mathrm{~V}$ vs. $\mathrm{Hg} / \mathrm{HgO}$ in $0.1 \mathrm{M} \mathrm{NaOH}$ at variable scan rates. A pair of oxidation and reduction peaks can be observed at $+0.52 \mathrm{~V}$ and $+0.37 \mathrm{~V}$ vs. $\mathrm{Hg} / \mathrm{HgO}$, respectively. Since Ni predominated in this compound and it is mainly consisted of the +2 oxidation state, the oxidation peak at $+0.52 \mathrm{~V}$ vs. $\mathrm{Hg} / \mathrm{HgO}$ was mainly attributed to the electrochemical oxidation of $\mathrm{Ni}^{2+}$. The cathodic peak at $+0.37 \mathrm{~V}$ vs. $\mathrm{Hg} / \mathrm{HgO}$ can be assigned to the reduction of surface-oxidized $\mathrm{Ni}^{3+}$. Since the oxidation of $\mathrm{Co}^{2+}$ occurs at similar electrode potential compared to $\mathrm{Ni}^{2+}$, the presence of $\mathrm{Co}^{2+}$ in the catalyst can enhance the oxidative current density of $\mathrm{Ni}_{0.7} \mathrm{Co}_{0.3}(\mathrm{OH})_{2}$, thus leading to enhanced sensitivity towards glucose sensing. Furthermore, the slight shifts in peak potentials with increasing scan rates suggest that the electrode process is rather sluggish. This is reasonable for most of the transition metal oxides and hydroxide materials since they usually suffer from low intrinsic conductivity. Figure $4 \mathrm{~b}$ shows the corresponding Randles-Sevick plot of Figure 4a. It shows a clear linear dependence of peak currents on the square root of scan rates, suggesting a diffusion-controlled redox process. This is reasonable because the electrochemical oxidation of $\mathrm{Ni}_{0.7} \mathrm{Co}_{0.3}(\mathrm{OH})_{2}$ involves hydroxide ions, which need to diffuse from the bulk solution to the surface of the electrode material. Figure $4 \mathrm{c}$ shows the $\mathrm{CV}$ curves of the $\mathrm{Ni}_{0.7} \mathrm{Co}_{0.3}(\mathrm{OH})_{2} / \mathrm{CP}$ electrode in the absence and presence of glucose. It is clear that in the presence of 0.5 and $2.5 \mathrm{mM}$ of glucose, the oxidation peak current increased significantly. The increase of peak current upon the addition of glucose suggests an electrochemical catalytic (EC') electrode process. Thus, the electrode reaction can be summarized as follows [9,35]:

$$
\begin{gathered}
\mathrm{Ni}_{0.7} \mathrm{Co}_{0.3}(\mathrm{OH})_{2}+\mathrm{OH}^{-} \rightarrow \mathrm{Ni}_{0.7} \mathrm{Co}_{0.3} \mathrm{OOH}+\mathrm{e}^{-}+\mathrm{H}_{2} \mathrm{O} ; \\
\mathrm{Ni}_{0.7} \mathrm{Co}_{0.3} \mathrm{OOH}+\text { glucose } \rightleftharpoons \mathrm{Ni}_{0.7} \mathrm{Co}_{0.3}(\mathrm{OH})_{2}+\text { glucolactone; }
\end{gathered}
$$

where (1) represents the electrochemical oxidation of $\mathrm{Ni}_{0.7} \mathrm{Co}_{0.3}(\mathrm{OH})_{2}(\mathrm{E})$, and (2) represents the heterogeneous catalytic process occurring on the surface of the electrode $\left(\mathrm{C}^{\prime}\right)$. 

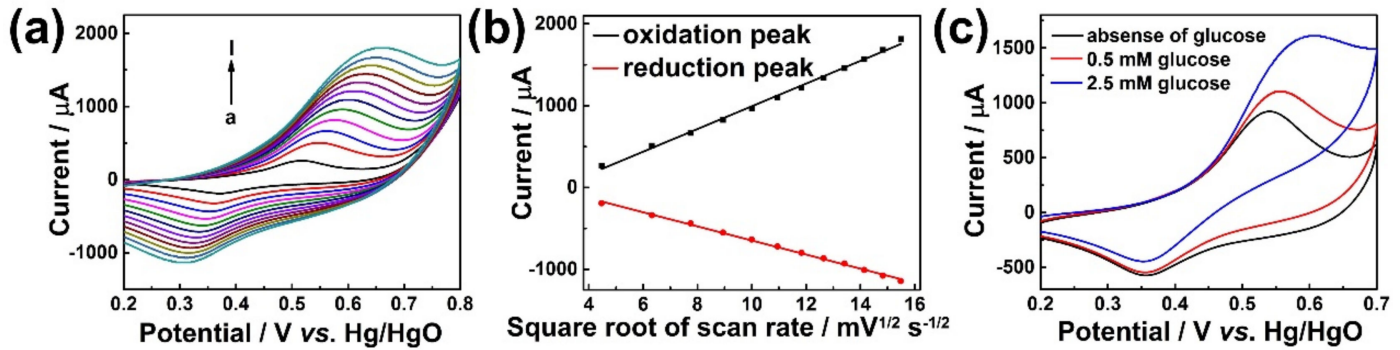

Figure 4. (a) Cyclic voltammograms of the $\mathrm{Ni}_{0.7} \mathrm{Co}_{0.3}(\mathrm{OH})_{2} /$ carbon paper $(\mathrm{CP})$ electrode scanned from +0.2 to $+0.8 \mathrm{~V}$ vs. $\mathrm{Hg} / \mathrm{HgO}$ in $0.1 \mathrm{M} \mathrm{NaOH}$ at variable scan rates. (b) The corresponding Randles-Sevick plot to (a). (c) The CV curve of the $\mathrm{Ni}_{0.7} \mathrm{Co}_{0.3}(\mathrm{OH})_{2}$ drop-casted carbon paper electrode in absence and presence of 0.5 and $2.5 \mathrm{mM}$ glucose.

Although it is rather difficult to determine the exact active surface areas, it is still reasonable to reveal the total surface areas that are exposed in the electrolyte. The different $\mathrm{Ni}_{\mathrm{x}} \mathrm{Co}_{1-\mathrm{x}}(\mathrm{OH})_{2} / \mathrm{CP}$ electrodes were firstly evaluated using CV by scanning in the non-Faradaic potential range (Figure S2). The corresponding plot of current difference against scan rates is shown in Figure 5a. It is clear that $\mathrm{Ni}_{0.7} \mathrm{Co}_{0.3}(\mathrm{OH})_{2}$ exhibited the highest $C_{d l}$ value, suggesting the largest surface areas exposed in the electrolyte solution. The large surface area can thus create more redox centers at the material surface, which can lead to increased current density. Thus, the increased current density may result in enhanced sensory sensitivity. In order to reveal the insight of electrode kinetics, electrochemical impedance spectroscopy (EIS) analyses were carried out for $\mathrm{Ni}_{\mathrm{x}} \mathrm{Co}_{1-\mathrm{x}}(\mathrm{OH})_{2} / \mathrm{CP}$. The Nyquist plots of different electrodes are shown in Figure $5 b$, and the corresponding equivalent circuit is shown in the insertion. The Rs values differed only slightly for the series resistance of all five samples, indicating that the electronic conductivity of the different $\mathrm{Ni}_{\mathrm{x}} \mathrm{Co}_{1-\mathrm{x}}(\mathrm{OH})_{2} / \mathrm{CP}$ are nearly the same. Moreover, the charge-transfer resistance $\left(R_{c t}\right)$ of $\mathrm{Ni}_{0.7} \mathrm{Co}_{0.3}(\mathrm{OH})_{2}$ was equal to $21.27 \Omega$, which is much smaller than other electrode materials, suggesting much faster charge transfer kinetics of $\mathrm{Ni}_{0.7} \mathrm{Co}_{0.3}(\mathrm{OH})_{2}$ at the interface between the electrocatalyst and electrolyte compared to other samples. Therefore, $\mathrm{Ni}_{0.7} \mathrm{Co}_{0.3}(\mathrm{OH})_{2}$ exhibited the largest electrochemical surface area and the fastest electrode kinetics among other materials; thus, it can be an excellent candidate for electrocatalytic glucose oxidation.
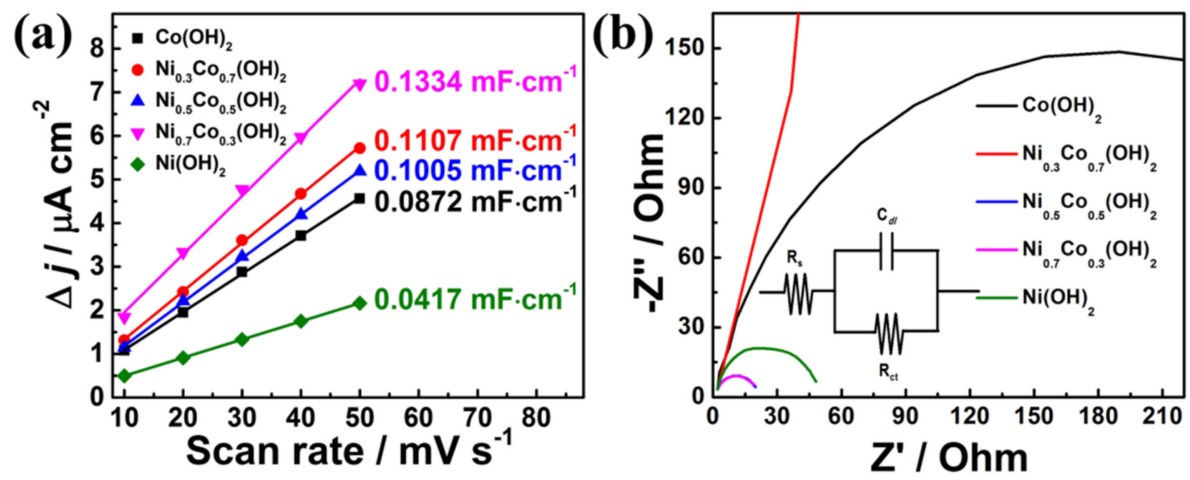

Figure 5. (a) The double-layer capacitance $\left(C_{d l}\right)$ of different $\mathrm{Ni}_{\mathrm{x}} \mathrm{Co}_{1-\mathrm{x}}(\mathrm{OH})_{2} / \mathrm{CP}$ electrodes, which were obtained from the cyclic voltammetry scanned in the non-Faradaic region. (b) Nyquist plots of $\mathrm{Ni}_{\mathrm{x}} \mathrm{Co}_{1-\mathrm{x}}(\mathrm{OH})_{2} / \mathrm{CP}$ in $0.1 \mathrm{M} \mathrm{NaOH}$ at their respective open circuit voltages.

\subsection{Sensory Evaluation of $\mathrm{Ni}_{x} \mathrm{Co}_{1-x}(\mathrm{OH})_{2} /$ Carbon Paper (CP) Towards Glucose Detection}

$\mathrm{Ni}_{0.7} \mathrm{Co}_{0.3}(\mathrm{OH})_{2} / \mathrm{CP}$ was firstly evaluated for glucose detection using chronoamperometry with stirring in $0.1 \mathrm{M} \mathrm{NaOH}$. Figure 6a shows the typical i-t curve of $\mathrm{Ni}_{0.7} \mathrm{Co}_{0.3}(\mathrm{OH})_{2} / \mathrm{CP}$ upon the addition of different concentrations of glucose performed at different potentials (i.e., $+0.5,+0.6$, and $+0.7 \mathrm{~V}$ vs. $\mathrm{Hg} / \mathrm{HgO}$ ). The current increased gradually with an increasing amount of glucose at three differential voltages, demonstrating that $\mathrm{Ni}_{0.7} \mathrm{Co}_{0.3}(\mathrm{OH})_{2}$ is sensitive to the change of glucose 
concentration. It is clear that the electrode potential at $+0.6 \mathrm{~V}$ vs. $\mathrm{Hg} / \mathrm{HgO}$ offers the best current response. The corresponding calibration graph for amperometric glucose detection on $\mathrm{Ni}_{0.7} \mathrm{Co}_{0.3}(\mathrm{OH})_{2} / \mathrm{CP}$ at $+0.6 \mathrm{~V}$ vs. $\mathrm{Hg} / \mathrm{HgO}$ is shown in Figure $6 \mathrm{~b}$. The slope of the linear part was consistent with the change of current density that accompanied each additional mole of glucose, which indicates the sensitivity of $1541 \mu \mathrm{A} \bullet \mathrm{mM}^{-1} \bullet \mathrm{cm}^{-2}$. The detection limit was determined to be $3.42 \mu \mathrm{M}(\mathrm{S} / \mathrm{N}=3)$. The sensory performance of $\mathrm{Ni}_{0.7} \mathrm{Co}_{0.3}(\mathrm{OH})_{2} / \mathrm{CP}$ is comparable to other $\mathrm{Ni}$ - or Co-based electrode materials (Table 1). It is worth noting that the $\mathrm{Ni}_{0.7} \mathrm{Co}_{0.3}(\mathrm{OH})_{2} / \mathrm{CP}$ electrode can offer high sensitivity towards glucose detection in $0.1 \mathrm{M} \mathrm{NaOH}$. This is attributed to the high electrochemical surface area determined by double-layer capacitance and fast electron transfer kinetics verified by EIS analysis. For comparison, amperometric glucose detection experiments were also carried out for $\mathrm{Co}(\mathrm{OH})_{2} / \mathrm{CP}, \mathrm{Ni}_{0.3} \mathrm{Co}_{0.7}(\mathrm{OH})_{2}$, $\mathrm{Ni}_{0.5} \mathrm{Co}_{0.5}(\mathrm{OH})_{2}$, and $\mathrm{Ni}(\mathrm{OH})_{2}$ at three electrode potentials of $+0.5,+0.6$, and $+0.7 \mathrm{~V} \mathrm{vs}$. $\mathrm{Hg} / \mathrm{HgO}$. It is clear that the sensitivities at $+0.6 \mathrm{~V}$ vs. $\mathrm{Hg} / \mathrm{HgO}$ were higher than that of +0.5 and $+0.7 \mathrm{~V}$ vs. $\mathrm{Hg} / \mathrm{HgO}$ for each sample, suggesting $+0.6 \mathrm{~V}$ vs. $\mathrm{Hg} / \mathrm{HgO}$ is the optimal electrode potential for glucose detection. Concerning the composition of the Ni-Co hydroxides, $\mathrm{Ni}_{0.7} \mathrm{Co}_{0.3}(\mathrm{OH})_{2} / \mathrm{CP}$ demonstrated higher sensitivity than that of the other samples at $+0.6 \mathrm{~V}$ vs. $\mathrm{Hg} / \mathrm{HgO}$. More detailed results of sensitivity and limit detection are shown in Table 2.

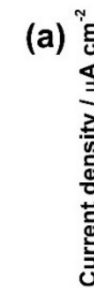

(b)
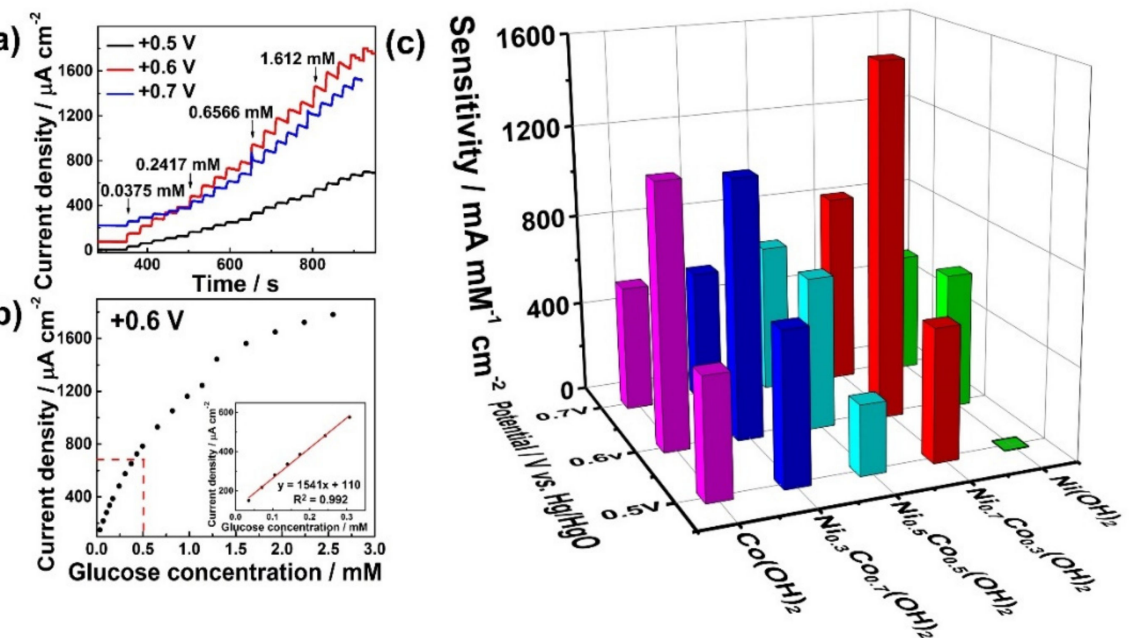

Figure 6. (a) Current responses of $\mathrm{Ni}_{0.7} \mathrm{Co}_{0.3}(\mathrm{OH})_{2} / \mathrm{CP}$ at $+0.5,+0.6$, and $+0.7 \mathrm{~V}$ vs. $\mathrm{Hg} / \mathrm{HgO}$ with the changing concentration of glucose. (b) The calibration plot of glucose concentration to the current density of (a); the illustration shows the linear section. (c) The sensitivities of different electrodes obtained by the slope of the linear part of different samples at $+0.5,+0.6$, and $+0.7 \mathrm{~V} \mathrm{vs}$. $\mathrm{Hg} / \mathrm{HgO}$.

Table 1. Summary of sensing performances of nickel, cobalt, and nanostructure-based electrodes.

\begin{tabular}{ccccc}
\hline Materials & Linear Range $(\mathbf{m M})$ & LOD $(\mu \mathbf{M})$ & Sensitivity $\left(\boldsymbol{\mu} \mathbf{A ~ m M ~ c m} \mathbf{~ m}^{-2}\right)$ & References \\
\hline $\mathrm{Ni}_{0.7} \mathrm{Co}_{0.3}(\mathrm{OH})_{2}$ & $0.002 \sim 0.8$ & 3.42 & 1541 & This work \\
$\mathrm{AuNPS} / \mathrm{Ni}(\mathrm{OH})_{2}$ & $0.002 \sim 6.0$ & 6.6 & 27.14 & {$[9]$} \\
$\alpha-\mathrm{Ni}(\mathrm{OH})_{2} / \mathrm{FTO}$ & $0.01 \sim 0.75$ & 2.5 & 446 & {$[36]$} \\
$\mathrm{Ni}(\mathrm{OH})_{2}$ & $0.004 \sim 3.5$ & 2.0 & 948 & {$[37]$} \\
$\mathrm{CuNps}-\mathrm{Co}(\mathrm{OH})_{2} \mathrm{Nfs} / \mathrm{Nif}$ & $0.001 \sim 0.25$ & 0.025 & 43.2 & {$[10]$} \\
$\mathrm{CoOOH}$ & $0.003 \sim 1.109$ & 1.37 & 526.8 & {$[38]$} \\
\hline
\end{tabular}

Table 2. Sensitivity of $\mathrm{Ni}_{\mathrm{x}} \mathrm{Co}_{1-\mathrm{x}}(\mathrm{OH})_{2} / \mathrm{CP}$ at different electrode potentials (vs. $\left.\mathrm{Hg} / \mathrm{HgO}\right)$.

\begin{tabular}{cccc}
\hline Sensitivity $\left(\boldsymbol{\mu A} \cdot \mathbf{m} \mathbf{M}^{-1} \cdot \mathbf{c m}^{-\mathbf{2}}\right)$ & $\mathbf{+ 0 . 5} \mathbf{~ V}$ & $\mathbf{+ 0 . 6} \mathbf{~ V}$ & $\mathbf{+ 0 . 7} \mathbf{~ V}$ \\
\hline $\mathrm{Co}(\mathrm{OH})_{2}$ & 518 & 1140 & 545 \\
$\mathrm{Ni}_{0.3} \mathrm{Co}_{0.7}(\mathrm{OH})_{2}$ & 653 & 1120 & 569 \\
$\mathrm{Ni}_{0.5} \mathrm{Co}_{0.5}(\mathrm{OH})_{2}$ & 301 & 660 & 646 \\
$\mathrm{Ni}_{0.7} \mathrm{Co}_{0.3}(\mathrm{OH})_{2}$ & 571 & 1541 & 832 \\
$\mathrm{Ni}(\mathrm{OH})_{2}$ & 4.21 & 592 & 525 \\
\hline
\end{tabular}


Selectivity testing is another important factor to be considered in order to evaluate the sensory performance of $\mathrm{Ni}_{0.7} \mathrm{Co}_{0.3}(\mathrm{OH})_{2} / \mathrm{CP}$ for glucose, since other bio-organic molecules, such as uric acid (UA), ascorbic acid (AA), galactose, acetaminophen (AP), and fructose, may interfere with the current response in real circumstances. Figure 7a shows the typical amperometric response of $\mathrm{Ni}_{0.7} \mathrm{Co}_{0.3}(\mathrm{OH})_{2} / \mathrm{CP}$ with the addition of $0.5 \mathrm{mM}$ glucose, $0.01 \mathrm{mM} \mathrm{UA}, 0.01 \mathrm{mM} \mathrm{AA}, 0.01 \mathrm{mM}$ galactose, $0.01 \mathrm{mM} \mathrm{AP}$, and $0.01 \mathrm{mM}$ fructose at $+0.6 \mathrm{~V}$ vs. the $\mathrm{Hg} / \mathrm{HgO}$ electrode potential. It is clear that the addition of $0.5 \mathrm{mM}$ glucose caused a significant increase in current density up to $728 \mu \mathrm{A} \mathrm{cm}{ }^{-2}$, whereas the addition of a small amount of other interferences caused negligible current responses (Figure $7 \mathrm{~b}$ ). It is worth mentioning that the concentrations of interferences are much lower than that of glucose, which is reasonable since those interferences in plasma have much lower concentrations than glucose. Therefore, $\mathrm{Ni}_{0.7} \mathrm{Co}_{0.3}(\mathrm{OH})_{2} / \mathrm{CP}$ can be a reasonable candidate to selectively detect glucose with a high sensitivity and low detection limits.
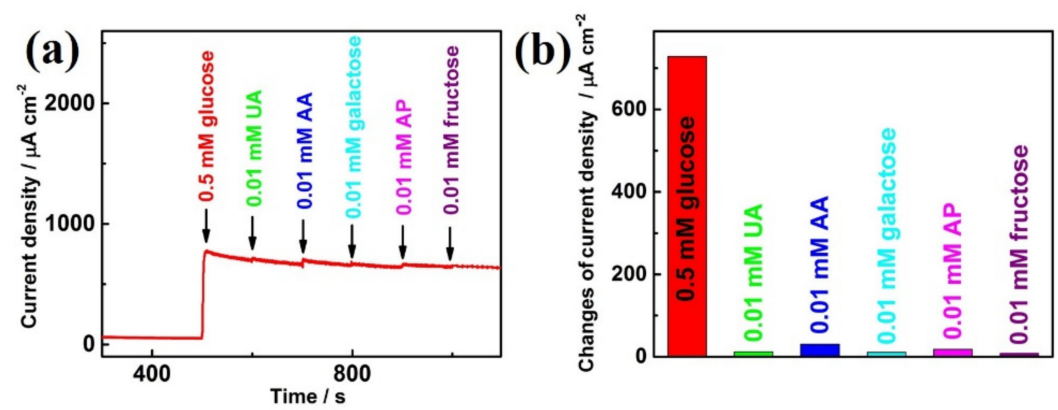

Figure 7. (a) Interference test of $\mathrm{Ni}_{0.7} \mathrm{Co}_{0.3}(\mathrm{OH})_{2} / \mathrm{CP}$ with $0.5 \mathrm{mM}$ glucose, $0.01 \mathrm{mM}$ uric acid (UA), 0.01 $\mathrm{mM}$ ascorbic acid (AA), $0.01 \mathrm{mM}$ galactose, $0.01 \mathrm{mM}$ acetaminophen (AP), $0.01 \mathrm{mM}$ fructose, and 0.5 mM glucose successively at $+0.6 \mathrm{~V}$ in $0.1 \mathrm{M} \mathrm{NaOH}$. (b) A plot that shows the changes in current density caused by the addition of glucose and other interferences.

Accordingly, although transition metal hydroxides have been widely explored as electrode materials for nonenzymatic glucose, such as $\mathrm{Ni}(\mathrm{OH})_{2}[9,35,37-40], \mathrm{Co}(\mathrm{OH})_{2}[10,38]$, and $\mathrm{Cu}(\mathrm{OH})_{2}[41,42]$, the presence of an additional transition metal indeed improved the current density response significantly, which is similar to previous works [43]. As it is shown in the XPS data, the electrode materials displayed both $\mathrm{Ni}$ and $\mathrm{Co}$ in both +2 and +3 oxidation states. Since the oxidation potentials between $\mathrm{Ni}^{2+}$ and $\mathrm{Co}^{2+}$ are similar under alkali conditions, the presence of $\mathrm{Co}^{2+}$ in the catalyst can enhance the oxidative current density of the $\mathrm{Ni}_{0.7} \mathrm{Co}_{0.3}(\mathrm{OH})_{2}$, thus leading to enhanced sensitivity towards glucose sensing. Besides, the rational design of hollow cubic $\mathrm{Ni}_{0.7} \mathrm{Co}_{0.3}(\mathrm{OH})_{2}$ nanosheets can provide a large electrochemical surface area, improved glucose diffusion pathways, and tuned conductivity that, thus, leads to an increased current density signal [44,45]. Moreover, since the electrochemical oxidation of $\mathrm{Ni}_{0.7} \mathrm{Co}_{0.3}(\mathrm{OH})_{2}$ is a hydroxide ion coupled reaction pathway, the enlarged surface area and the hollow cubic structure can also boost the diffusion rate of $-\mathrm{OH}$ within the material. This is may be one of the reasons that this rationally designed hollow cubic structure can offer a high current density compared to other reported works. Thus, the increased oxidative current density of $\mathrm{Ni}_{0.7} \mathrm{Co}_{0.3}(\mathrm{OH})_{2}$ can increase the sensitivity towards glucose sensing.

\section{Conclusions}

$\mathrm{Ni}_{\mathrm{x}} \mathrm{Co}_{1-\mathrm{x}}(\mathrm{OH})_{2}$ nanosheets assembled hollow cubes with controllable compositions of $\mathrm{Ni}$ and Co have been investigated for electrochemical glucose determination. Mixed Ni and Co metal ions in hydroxide may tune the nanostructures and conductivities of the hydroxides, thus increasing the active surface area, tuning the glucose diffusion pathways, and improving the activity of metal hydroxides towards glucose sensing. The $\mathrm{Ni}_{0.7} \mathrm{Co}_{0.3}(\mathrm{OH})_{2} / \mathrm{CP}$ electrode displayed the best glucose sensory performance among other ratios, with highly selectivity and sensitivity towards electrochemical catalytic glucose oxidation. This hollow, hierarchical structure, synthetic approach could also be an 
effective approach for the development of other highly efficient electrode materials for nonenzymatic glucose sensors.

Supplementary Materials: The following are available online at http://www.mdpi.com/1424-8220/19/13/2938/s1, Figure S1: The TEM images of (a) $\mathrm{Co}(\mathrm{OH})_{2}$, (b) $\mathrm{Ni}_{0.3} \mathrm{Co}_{0.7}(\mathrm{OH})_{2}$, (c) $\mathrm{Ni}_{0.5} \mathrm{Co}_{0.5}(\mathrm{OH})_{2}$, and (d) $\mathrm{Ni}(\mathrm{OH})_{2}$ hollow cubes; Figure S2: Cyclic voltammograms plots of different $\mathrm{Ni}_{x} \mathrm{Co}_{1-\mathrm{x}}(\mathrm{OH})_{2} / \mathrm{CP}$ at various scan rates $\left(10-50 \mathrm{mV} \mathrm{s}^{-1}\right)$ scan in the non-Faradaic potential window.

Author Contributions: Conceptualization, Y.Z.; Data curation, F.S. and Y.W.; Formal analysis, F.S.; Funding acquisition, Y.Z. and J.Z.; Investigation, F.S., J.Z., and X.Y.; Methodology, F.S., Y.W., and J.Z.; Resources, Y.Z.; Supervision, Y.Z. and J.Z.; Validation, Y.Z.; Visualization, Y.Z.; Writing—original draft, S.W. and Y.Z.; Writing-review \& editing, Y.Z.

Funding: This research was funded by the National Natural Science Foundation of China, grant number 21805308; the Shandong Provincial Natural Science Foundation, China, grant number ZR2017QB015; and the Fundamental Research Funds for the Central Universities, grant number 19CX05001A.

Acknowledgments: J.Z. thanks the finical support provided by the Taishan Scholar Project of Shandong province.

Conflicts of Interest: The authors declare no conflict of interest.

\section{References}

1. Wang, J. Electrochemical glucose biosensors. Chem. Rev. 2008, 108, 814-825. [CrossRef] [PubMed]

2. Park, S.; Boo, H.; Chung, T.D. Electrochemical non-enzymatic glucose sensors. Anal. Chim. Acta 2006, 556, 46-57. [CrossRef] [PubMed]

3. Toghill, K.E.; Compton, R.G. Electrochemical Non-enzymatic Glucose Sensors: A Perspective and an Evaluation. Int. J. Electrochem. Sci. 2010, 5, 1246-1301.

4. Wang, J. Glucose Biosensors: 40 Years of Advances and Challenges. Sens. Update 2002, 10, 107-119. [CrossRef]

5. Akhtar, N.; El-Safty, S.A.; Abdelsalam, M.E.; Kawarada, H. One-Pot Fabrication of Dendritic NiO@carbon-nitrogen Dot Electrodes for Screening Blood Glucose Level in Diabetes. Adv. Healthc. Mater. 2015, 4, 2110-2119. [CrossRef]

6. Clark, L.C.; Lyons, C. Electrode systems for continuous monitoring in cardiovascular surgery. Ann. N. Y. Acad. Sci. 1962, 102, 29-45. [CrossRef] [PubMed]

7. Wang, S.; Wang, C.; Wei, G.; Xiao, H.; An, N.; Zhou, Y.; An, C.; Zhang, J. Non-enzymatic glucose sensor based on facial hydrothermal synthesized $\mathrm{NiO}$ nanosheets loaded on glassy carbon electrode. Colloids Surf. A: Physicochem. Eng. Asp. 2016, 509, 252-258. [CrossRef]

8. Wilson, R.; Turner, A.P.F. Glucose oxidase: an ideal enzyme. Biosens. Bioelectron. 1992, 7, 165-185. [CrossRef]

9. Xu, J.; Chen, T.; Qiao, X.; Sheng, Q.; Yue, T.; Zheng, J. The hybrid of gold nanoparticles and $\mathrm{Ni}(\mathrm{OH})_{2}$ nanosheet for non-enzymatic glucose sensing in food. Colloids Surf. A: Physicochem. Eng. Asp. 2019, 561, 25-31. [CrossRef]

10. Wang, L.; Zhuang, S.; Wang, L.; Wang, N.; Mo, H.; Tang, Y.; Chen, Y.; Sun, Y.; Wan, P. One step synthesis of hierarchical $\mathrm{Cu}$ nanoparticles- $\mathrm{Co}(\mathrm{OH})_{2}$ nanoflakes/Nifoam electrode for ultrasensitive detection of glucose. Appl. Surf. Sci. 2019, 468, 773-781. [CrossRef]

11. Sun, F.; Wang, Z. Highly-branched dendrite cuprous oxide films for non-enzymatic amperometric glucose sensor. Mater. Lett. 2019, 234, 62-65. [CrossRef]

12. Raza, M.H.; Movlaee, K.; Wu, Y.; El-Refaei, S.M.; Karg, M.; Leonardi, S.G.; Neri, G.; Pinna, N. Tuning the $\mathrm{NiO}$ Thin Film Morphology on Carbon Nanotubes by Atomic Layer Deposition for Enzyme-Free Glucose Sensing. ChemElectroChem 2019, 6, 383-392. [CrossRef]

13. Ma, M.; Zhu, W.; Zhao, D.; Ma, Y.; Hu, N.; Suo, Y.; Wang, J. Surface engineering of nickel selenide nanosheets array on nickel foam: An integrated anode for glucose sensing. Sens. Actuators B Chem. 2019, 278, 110-116. [CrossRef]

14. Li, Y.; Xie, M.; Zhang, X.; Liu, Q.; Lin, D.; Xu, C.; Xie, F.; Sun, X. Co-MOF nanosheet array: A high-performance electrochemical sensor for non-enzymatic glucose detection. Sens. Actuators B Chem. 2019, 278, 126-132. [CrossRef]

15. Li, W.; Lv, S.; Wang, Y.; Zhang, L.; Cui, X. Nanoporous gold induced vertically standing 2D NiCo bimetal-organic framework nanosheets for non-enzymatic glucose biosensing. Sens. Actuators B Chem. 2019, 281, 652-658. [CrossRef] 
16. Heyser, C.; Schrebler, R.; Grez, P.J. New route for the synthesis of nickel (II) oxide nanostructures and its application as non-enzymatic glucose sensor. Electroanal. Chem. 2019, 832, 189-195. [CrossRef]

17. Zhu, H.; Li, L.; Zhou, W.; Shao, Z.; Chen, X.J. Advances in non-enzymatic glucose sensors based on metal oxides. Mater. Chem. B 2016, 4, 7333-7349. [CrossRef]

18. Niu, X.; Li, X.; Pan, J.; He, Y.; Qiu, F.; Yan, Y. Recent advances in non-enzymatic electrochemical glucose sensors based on non-precious transition metal materials: opportunities and challenges. RSC Adv. 2016, 6, 84893-84905. [CrossRef]

19. Wu, H.; Yan, L.; Fu, L.; Jin, L. Fabrication and electrochemical properties of alizarin-aminophenylboronic acid ensembled with layered double hydroxide for glucose sensing selectivity. Colloids Surf. A Physicochem. Eng. Asp. 2019, 560, 92-97. [CrossRef]

20. Xu, J.; Qiao, X.; Arsalan, M.; Cheng, N.; Cao, W.; Yue, T.; Sheng, Q.; Zheng, J. Preparation of one dimensional silver nanowire/nickel-cobalt layered double hydroxide and its electrocatalysis of glucose. J. Electroanal. Chem. 2018, 823, 315-321. [CrossRef]

21. Wang, F.; Zhang, Y.; Liang, W.; Chen, L.; Li, Y.; He, X. Non-enzymatic glucose sensor with high sensitivity based on Cu-Al layered double hydroxides. Sens. Actuators B Chem. 2018, 273, 41-47. [CrossRef]

22. Ni, G.; Cheng, J.; Dai, X.; Guo, Z.; Ling, X.; Yu, T.; Sun, Z. Integrating Ultrathin Polypyrrole Framework on Nickel-Cobalt Layered Double Hydroxide as an Amperometric Sensor for Non-enzymatic Glucose Determination. Electroanalysis 2018, 30, 2366-2373. [CrossRef]

23. Kumar, P.A.; Stanley, J.; Babu, T.G.S.; Suneesh, P.V. Synthesis of Nickel-Aluminium Layered Double Hydroxide and itsApplication in Non-Enzymatic Glucose Sensing. Mater. Today Proc. 2018, 5, 16125-16131. [CrossRef]

24. Samuei, S.; Fakkar, J.; Rezvani, Z.; Shomali, A.; Habibi, B. Synthesis and characterization of graphene quantum dots/CoNiAl-layered double-hydroxide nanocomposite: Application as a glucose sensor. Anal. Biochem. 2017, 521, 31-39.

25. Lu, Y.; Jiang, B.; Fang, L.; Fan, S.; Wu, F.; Hu, B.; Meng, F. Synthesis and characterization of graphene quantum dots/CoNiAl-layered double-hydroxide nanocomposite: Application as a glucose sensor. Electroanalysis 2017, 29, 1755-1761. [CrossRef]

26. Chen, J.; Sheng, Q.; Wang, Y.; Zheng, J. Dispersed Nickel Nanoparticles on Flower-like Layered Nickel-Cobalt Double Hydroxides for Non-enzymic Amperometric Sensing of Glucose. Electroanalysis 2016, 28, 979-984. [CrossRef]

27. Fu, S.; Fan, G.; Yang, L.; Li, F. Non-enzymatic glucose sensor based on Au nanoparticles decorated ternary $\mathrm{Ni}$-Al layered double hydroxide/single-walled carbon nanotubes/graphene nanocomposite. Electrochim. Acta 2015, 152, 146-154. [CrossRef]

28. Wang, X.; Zheng, Y.; Yuan, J.; Shen, J.; Hu, J.; Wang, A.-J.; Wu, L.; Niu, L. Three-dimensional NiCo Layered Double Hydroxide Nanosheets Array on Carbon Cloth, Facile Preparation and Its Application in Highly Sensitive Enzymeless Glucose Detection. Electrochim. Acta 2017, 224, 628-635. [CrossRef]

29. Li, H.; Zhang, L.; Mao, Y.; Wen, C.; Zhao, P. A Simple Electrochemical Route to Access Amorphous Co-Ni Hydroxide for Non-enzymatic Glucose Sensing. Nanoscale Res. Lett. 2019, 14, 135. [CrossRef]

30. Cui, J.; Li, Z.; Liu, K.; Li, J.; Shao, M. A bifunctional nonenzymatic flexible glucose microsensor based on CoFe-Layered double hydroxide. Nanoscale Adv. 2019, 1, 948-952. [CrossRef]

31. Nai, J.; Wang, S.; Bai, Y.; Guo, L. Amorphous $\mathrm{Ni}(\mathrm{OH})_{2}$ nanoboxes: fast fabrication and enhanced sensing for glucose. Small 2013, 9, 3147-3152. [CrossRef] [PubMed]

32. Wang, Y.; Jiang, K.; Zhang, H.; Zhou, T.; Wang, J.; Wei, W.; Yang, Z.; Sun, X.; Cai, W.-B.; Zheng, G. Bio-inspired leaf-mimicking nanosheet/nanotube heterostructure as a highly efficient oxygen evolution catalyst. Adv. Sci. 2015, 2, 1500003. [CrossRef] [PubMed]

33. Lee, D.; Xia, Q.X.; Mane, R.S.; Yun, J.M.; Kim, K.H. Direct successive ionic layer adsorption and reaction (SILAR) synthesis of nickel and cobalt hydroxide composites for supercapacitor applications. J. Alloy. Compd. 2017, 722, 809-817. [CrossRef]

34. Lee, D.U.; Kim, B.J.; Chen, Z. One-pot synthesis of a mesoporous $\mathrm{NiCo}_{2} \mathrm{O}_{4}$ nanoplatelet and graphene hybrid and its oxygen reduction and evolution activities as an efficient bi-functional electrocatalyst. J. Mater. Chem. A 2013, 1, 4754-4762. [CrossRef]

35. Wu, X.; Li, F.; Zhao, C.; Qian, X. One-step construction of hierarchical $\mathrm{Ni}(\mathrm{OH})_{2} / \mathrm{RGO} / \mathrm{Cu}_{2} \mathrm{O}$ on $\mathrm{Cu}$ foil for ultra-sensitive non-enzymatic glucose and hydrogen peroxide detection. Sens. Actuators B Chem. 2018, 274, 163-171. [CrossRef] 
36. Martins, P.R.; Rocha, M.A.; Angnes, L.; Toma, H.E.; Araki, K. Highly sensitive amperometric glucose sensors based on nanostructured $\alpha-\mathrm{Ni}(\mathrm{OH})_{2}$ electrodes. Electroanalysis 2011, 23, 2541-2548. [CrossRef]

37. Chelaghmia, M.L.; Nacef, M.; Affoune, A.M.; Pontié, M.; Derabla, T. Facile Synthesis of Ni(OH $)_{2}$ Modified Disposable Pencil Graphite Electrode and its Application for Highly Sensitive Non-enzymatic Glucose Sensor. Electroanalysis 2018, 30, 1117-1124. [CrossRef]

38. Zhang, L.; Yang, C.; Zhao, G.; Mu, J.; Wang, Y. Self-supported porous CoOOH nanosheet arrays as a non-enzymatic glucose sensor with good reproducibility. Sens. Actuators B Chem. 2015, 210, 190-196. [CrossRef]

39. Yang, J.; Cho, M.; Lee, Y. Synthesis of hierarchical Ni(OH)2 hollow nanorod via chemical bath deposition and its glucose sensing performance. Sens. Actuators B Chem. 2016, 222, 674-681. [CrossRef]

40. Lu, P.; Lei, Y.; Lu, S.; Wang, Q.; Liu, Q. Three-dimensional roselike alpha-Ni(OH)(2) assembled from nanosheet building blocks for non-enzymatic glucose detection. Anal. Chim. Acta 2015, 880, 42-51. [CrossRef]

41. Zhou, S.; Feng, X.; Shi, H.; Chen, J.; Zhang, F.; Song, W. Direct growth of vertically aligned arrays of $\mathrm{Cu}(\mathrm{OH})_{2}$ nanotubes for the electrochemical sensing of glucose. Sens. Actuators B Chem. 2013, 177, 445-452. [CrossRef]

42. Yang, Y.J.; Li, W.; Chen, X. Highly enhanced electrocatalytic oxidation of glucose on $\mathrm{Cu}(\mathrm{OH}) 2 / \mathrm{CuO}$ nanotube arrays modified copper electrode. J. Solid State Electrochem. 2012, 16, 2877-2881. [CrossRef]

43. Martins, P.R.; Parussulo, A.L.A.; Toma, S.H.; Rocha, M.A.; Toma, H.E.; Araki, K. Highly stabilized alpha- $\mathrm{NiCo}(\mathrm{OH})_{2}$ nanomaterials for high performance device application. J. Power Sources 2012, 218, 1-4. [CrossRef]

44. Cui, Z.; Yin, H.; Nie, Q. Controllable preparation of hierarchically core-shell structure NiO/C microspheres for non-enzymatic glucose sensor. J. Alloy. Compd. 2015, 632, 402-407. [CrossRef]

45. Cui, Z.; Yin, H.; Nie, Q.; Qin, D.; Wu, W.; He, X. Hierarchical flower-like NiO hollow microspheres for non-enzymatic glucose sensors. J. Electroanal. Chem. 2015, 757, 51-57. [CrossRef]

(C) 2019 by the authors. Licensee MDPI, Basel, Switzerland. This article is an open access article distributed under the terms and conditions of the Creative Commons Attribution (CC BY) license (http://creativecommons.org/licenses/by/4.0/). 